\title{
Political Discourses Around the Single Union Law and Conceptions about the Organisation of the World of Labour: From Historical to Current Dilemmas
}

\author{
Virgílio Amaral
}

Centro de Estudos Sociais, Coimbra University; Email: virgilio.amaral@gmail.com

Doi:10.5901/ajis.2015.v4n3s1p262

\begin{abstract}
The current research analyses political discourses around the controversy of the Single Union Law, which occurred in the postApril 25th revolutionary context, to understand how the contending parties built different conceptions about the arrangements of labour organisations. By reconstructing the meanings conveyed in the arguments, it is observed that each party invests some words - Unions, Freedom - with different meanings. Additionally, it is observed that each side tends to use certain rhetorical mechanisms as listed by Castro (2002), Amaral (2013) and Amaral \& Pereira (2014). The conclusion provides a historical and ideological overview of the different main conceptions and dilemmas yielded in the discourse analysis provided, along with the dilemmas that labour unions are confronted with in the current times, namely considering the issue of job insecurity.
\end{abstract}

Keywords: Portugal, 25 April 1974 revolution, Single Union Law, political discourses, conceptions about labour organisation

To Ana Tereso, in Memoria

\section{Introduction}

The present research covers underlying rhetorical mechanisms in the political discourses around the polemic in the passing of the law on the principle of Union Uniqueness in the revolutionary context after the 25th of April, 1974. This polemic was the first great public confrontation between the Socialist Party (PS, Partido Socialista) and its ally in the Provisional Government at the time, the Democratic Popular Party (PPD, Partido Popular Democrático) - which gave rise to the current Social-Democrat Party (PSD, Partido Social Democrata) - on the one hand, and the Portuguese Communist Party (PCP, Partido Comunista Português) and its ally in the labour and union scope, Intersindical, on the other hand.

According to findings from previous works around such polemic (Amaral, 2014; Brito \& Rodrigues, 2013; Silva et al., 2011; Valente, 2001; Varela, 2014), the existence of different conceptions about the desirable forms of arrangement between the referred political formations and Intersindical was verified. These were later at the origin of the current Central Geral dos Trabalhadores Portugueses/ Intersindical Nacional (CGTP) - associated with PCP and which replaced Intersindical - and the União Geral dos Trabalhadores (UGT) - associated with PS and PSD-, the two Federal Cores in Portugal since the 1980s.

As it can be verified in the analysis of the works by Amaral (2013), Amaral and Pereira (2014), Castro (2002), Castro and Batel (2008), among others, different strategies and rhetorical mechanisms as well as mechanisms for the construction of discursive argumentation can convey and articulate with different conceptions (regarding the content of the discourses) about the topic of discursive polemics - in the case of the present work, the forms of unionism and labour organisation. Identical contents -for example, "Freedom", as it can be seen in this work - can assume different meanings according to the discursive strategies, resulting in different conceptions of "Freedom".

\section{Objectives}

Based on a previous historical analysis and identification of the main discursive contents around the polemic of the Law on Union Uniqueness (Amaral, 2014), the present research has the main objective of identifying the mechanisms and discursive structures articulated with the political rhetoric of the time. This is underpinned in the construction of socialpolitical meanings around this polemic, namely by the Intersindical and the party formations that were in the origin of the two union confederations existing today: PS, PPD and PCP.

To this effect, an analysis of a corpus of news discourses produced by the leaders of the aforementioned 
organisations in Portuguese newspapers at a national scope was made, as well as the analysis of party communications and news from the PCP's official bodies (Avante), PPD's (Povo Livre), PS' (Portugal Socialista) and Intersindical (Alavanca).

A second objective, which results from the findings of this research, consists on the explanation of the programming and ideological perspectives, preconized at the time, regarding the forms of labour organisation by the parties intervening in the quarrel.

The aim of the conclusive considerations is to relate these ideological dichotomies that result from a dilemmatic analysis of the discourses, to the history of unionism and the respective theoretical and ideological currents, as well as highlighting the problems and new social dilemmas faced by current union organisations.

\section{Theoretical and Methodological Considerations about the Analysis of the Rhetorical Discourse}

Perelman (1997), the philosopher responsible for the New Rhetoric study movement, claims the bases of such approach by Aristotle. In Organon, Aristotle distinguishes between two types of reasoning: analytical reasoning, which aims to relate the truth of the premises with that of the conclusions; and dialectic reasoning, based on premises formed by generally accepted opinions that create other theories that may be controversial acceptable, with the aim to persuade.

The rhetorical discourse is associated with this dialectic reasoning. Therefore, for example, the domain of political, philosophical, literary and even legal argumentation, "is of the plausible, the likely, in the measure that ... it escapes the certainties of calculation" (Perelman \& Olbrechts-Tyteca, 2006, p. 9).

In this work, we have adopted the perspectives on rhetorical discourse used in Social Psychology, both in Billig's Rhetorical Psychology (1991, 2012), Van Dijk's Critical Analysis of the Discourse (2006) and the analysis of argument construction mechanisms (Amaral, 2013; Amaral \& Pereira, 2014; Castro, 2002; Potter, 1996).

The model of analysis proposed by Potter (1996) is also considered, resumed by Castro (2002) and in some aspects focused on by Van Dijk (2006), which enables the identification of rhetorical mechanisms that are inherent to persuasive discourse: the extremism of arguments aiming to predispose an audience to an action, or the inverse, minimisation; the description of arguments using factual data; argumentation by inoculation (intending to show the audience that there is no interest by the subject in the argument presented); the distancing mechanism (assuming neutrality and intending that nothing will be proven); the presentation of credentials in argumentation (using categories of subjects with a particular knowledge about the issue, to make the message believable).

\section{4. $\quad$ Findings}

Article by Salgado Zenha (leader of the PS): "Unidade Sindical ou Medo à Liberdade?" (Union Unity or Fear of Freedom?") - Diário de Notícias, 07/01/1975

\footnotetext{
Evoking "union" and "association" freedom, as per the Armed Forces Programme (MFA, the movement that deposed the fascist regime on the 25th of April, 1974, in Portugal), it accuses the Law of Union Uniqueness as being "unconstitutional". The argument denotes aspects of fact description, but it is also construed in the form of a confession, about the stance taken regarding this Law:
}

In the draft law on unions, a single union confederation is imposed. Now, and respecting the contrary opinion, I consider this disposition as unconstitutional. As it is known, the Armed Forces Movement Programme is currently a real constitutional charter. Additionally, freedom of association and union freedom (a particular aspect of freedom of association) are violated, if the uniqueness of the union confederation is imposed. Freedom implies freedom of choice and paths. Without it, there is no freedom. (Zenha, 1975, p.7)

"O PPD contra os sindicatos únicos" ("PPD against single unions") - Povo livre, 08/10/1974

Under the title "Single unions are the most certain path to the return to oppression", PPD expresses its concerns regarding the topic of "Union Freedom" in this communication about the Law on Union Uniqueness: "Regarding the recent stands taken about union unity, PPD could not but insist on the need for this to never sacrifice union freedom" ("O PPD contra os sindicatos únicos", 1974, p. 1).

Evoking this Freedom, the excerpt above seems to aim to warn the audience against the consequences of the Law on Union Uniqueness (inoculation mechanism). In fact, it is what the following excerpt states, written in the form of a 
confession of a political stance taken: "Union unity ... is not the result of the power of the law or of any limitations to the right of union freedom" ("O PPD contra os sindicatos únicos", 1974, p. 1).

In the following sentence, the problem with union organisation is again linked to the issue of "union freedom", mentioning the credentials of the International Labour Organisation (ILO): "Unitary unionism is only accurate in a regime of union freedom, according to the Convention no. 87 of the ILO" ("O PPD contra os sindicatos únicos", 1974, p. 1).

"O Partido Socialista não se deixará satelizar" (The Socialist Party will not allow others to control it") - Portugal Socialista, 17/01/1975

This special issue of Portugal Socialista reports the discourses delivered at a demonstration organised by the PS against the Law on Union Uniqueness on the 16th of January, 1975.

Our analysis will be focused on the discourse by Salgado Zenha, due to his relevance in the counter-arguments of the stands advocated by the PCP and Intersindical.

The following argument, construed as a confession, raises the issue of union freedom and the unity of workers which, as can be later seen, is what is intended in a "unity in freedom":

I was - let me tell you - completely astonished by the audacity of that project. It was becoming evident that it was a betrayal of union freedom and a betrayal of the unity of workers as it is understood by true democrats and true socialists. (Zenha, 1975, p. 6).

The following excerpt of Zenha's discourse, presented in the form of a confession and using the expression "restriction of the workers' class", is coupled with the workers' arguments on freedom: "This project surprised me not only because it imposes a single Union Confederation, but also because it imposes a single union and a whole set of provisions that are in fact restraining the working class" (Zenha, 1975, p. 6).

In fact, the aim is to have "unity in freedom", as expressed in the following discursive unit, construed as a confession: "since ever and from the beginning, in articles published in the press, in conferences with our comrades, in information events, we have sustained our principles of "unity in freedom" (Zenha, 1975, p. 6).

Interview to Sá Carneiro (leader of the PPD) - "Social-democracia não mantém sistema capitalista" ("Social-democracy does not maintain a capitalist system") - A Capital, 21/01/1975

Questioned about the PPD's sociological profile and stating that "the PPD is a party that covers all the layers of the working class" (Carneiro, 1975, p. 15), Sá Carneiro said, regarding the dispute around the political representation of the working class: "we do not intend to be the party of the workers because we understand that workers are nobody's monopoly and they should freely choose among parties, according to their respective programmes" (Carneiro, 1975, p. 15).

Then, he declares, to contest the Law on Union Uniqueness, using the rhetorical mechanism of confession and counterpoising the problem of "freedom" versus the imposition of unity by the law: "we advocate a kind of unitary unionism that expresses the result of the exercise of freedom and not a legal imposition" (Carneiro, 1975, p.15).

"Unidade, a vontade dos trabalhadores" ("Unity, the workers' will") - Alavanca, 09/12/1974

Citing a document produced at a plenary by Intersindical, on the 30th of November, 1974, another point of view is presented, also in the form of a confession. It associates the issue of "union unity" with the "consecration of uniqueness" by the law, aiming to have unionism "at the service of the working class".

The unity of the Portuguese union movement is not just a tradition. It is a historical need. The consecration of uniqueness will be a desirable contribution towards the advocacy and reinforcement of union unity. In terms of the advocacy and reinforcement of democratic freedom, the only one that can serve the interests of the workers, this consecration of uniqueness will, jointly with the principles of independence, autonomy and democracy of organisations as well as the right to perform union actions in companies and the legal protection of leaders and union delegates, enable the construction of a powerful union movement at the service of the working class, the Portuguese people and the country. ("Unidade, a vontade dos trabalhadores", 1974, p. 1)

Union pluralism is identified with "division", in an argument construed as a confession of Intersindical's stand: 
The course of time came to prove that workers could not only trust their will for unity. For the interests of some and incomprehension of others, public stands started to arise with forces that are external to the workers, seeking to divide the union movement by introducing pluralism. ("Unidade, a vontade dos trabalhadores", 1974, p. 2)

Freedom, understood as "freedom of classes" (against "abstract freedom" and "liberalism") and class unionism are explained in the following stand taken by Intersindical (confession mechanism): "Freedom is not an abstract concept. Freedom has a class content ... we have to distinguish between freedom and liberalism." ("Unidade, a vontade dos trabalhadores", 1974, p.2)

Note by the Political Commission of the PCP's Central Committee (13/01/75) (Press Release)

Using the maximisation of the demonstration convened by Intersindical on the 14th of January, which "should be seen as an unequivocal statement by workers that union uniqueness is inscribed in the law", according to the PCP, predisposes the audience to take part:

The demonstration taking place in Lisbon today should be seen as an unequivocal statement by workers that union uniqueness should become law and ... the PCP exhorts all workers and people to actively take part in this important demonstration and to make it a grand and serene expression of the people's will. (PCP, 1975)

Carlos Carvalhas (leader of the PCP) - "Deve respeitar-se a vontade dos trabalhadores" "The will of the workers should be respected") - Diário de Notícias, 13/01/1975

Using the description of the wording of the Act, the audience is later warned against unionist pluralism, reported as a workers division in favour of the great capital, or partisan unionism:

It is also intended that there should exist unions that are independent from employers' organisations and political parties and maybe this is where we are touching a sore point. The great capital is interested in dividing workers and certain political parties with little influence in the working class are also interest in unionist pluralism so that they can form their own partisan unions. (Carvalhas, 1975, p. 7)

Using the credentials from the findings of the consultations with workers, but also with an argument that maximises its results ("smashing majority of workers", "thousands of workers", it justifies the Law on Union Uniqueness: "The smashing majority of workers and unions has publicly chosen union uniqueness in hundreds of meetings and polls with thousands of workers" (Carvalhas, 1975, p. 7).

\section{"A Lição de 14 de Janeiro" ("The lesson from January 14th"), Editorial - Avante, 16/01/1975}

Intersindical's demonstration on the 14th of January had its dimension rhetorically maximised and presented as "the most powerful and significant argument" ("A lição de 14 de Janeiro", 1975, p. 2) by the referred "popular movement": "The grand popular demonstrated organised by Intersindical . . . is the most powerful and significant argument against those who are not truly interested in reinforcing and revitalising the popular component of the new democratic process" ("A lição de 14 de Janeiro", 1975, p. 2).

"Intersindical's great demonstration: Who is afraid of the People? ("A grande manifestação da Intersindical: Quem tem medo do Povo?") - Alavanca, 17/01/1975

It reports on Intersindical's demonstration on the 14th of January, maximising the event. Again, it approaches the issue of freedom - the "authentic freedom" for which the workers were fighting - counterpoising it to the "formal" freedom and democracy: "Portuguese workers fighting for an authentic democracy and an authentic freedom, not for the formal freedom and democracy that economic power directly or indirectly gives to exploiters, i.e. the freedom to continue exploiting and taking over political power again." ("A grande manifestação da Intersindical: Quem tem medo do Povo?", 1975, p. 2).

\section{Speech by Carlos Carvalho (leader of Intersindical) - Alavanca, 17/01/1975}

In the form of a confession, it explains yet again Intersindical's understanding of "union freedom" associated with 
class unionism, as opposed to "union pluralism":

We have all taken a stance, in a decisive and firm manner, about what we understand by union freedom, a principle we wish to be consecrated in Law. In our opinion - the workers - union freedom is an expression that opposes to union pluralism by nature. (Carvalho, 1975, p. 4)

It identifies union pluralism as a "union divide" which will be of interest to "the great monopolist capital": "We do not want a union divide because we know very well who is behind these manoeuvers. We know it is the employers ... that are interested in weakening the union movement through its divide." (Carvalho, 1975, p. 4).

Carlos Carvalho finishes his speech associating the Law on Union Uniqueness with a form of class unionism: "Only the law on union uniqueness will enable the consequence advocacy of the interests of the working class" (Carvalho, 1975, p. 4).

"Política clara e transparente" ("A clear and transparent policy") - Avante, 23/01/1975

With an argument presented as a confession of a stance taken, "union pluralism" is refuted, referencing yet again the integration of unions in a class-based scope: "Union pluralism will lead to the creation of competing unions, each with an internal life subordinated to a partisan tendency (...) where the real class spirit would be camouflaged by a sect-like spirit that would enliven the union itself." ("Política clara e transparente", 1975, p. 2).

It is reasserted that the question is about "class independence" to refute yet again "union pluralism":

Union freedom can only be assured by uniqueness. The essential about union independence is class independence, the independence in the fight against exploitation in the defence of the interests of the workers. Union pluralism would represent the absolute control of unions by parties, groups of professional chieftains or the employers themselves. ("Politica clara e transparente", 1975, p. 2)

\section{Discussion and Concluding Remarks}

\subsection{Rhetorical mechanisms on Union Uniqueness}

PS and PPD - They mainly use the rhetorical mechanism of argumentation by confession of a position taken invoking "union freedom" (inscribed in the MFA's Programme) and the argument is used to show that, despite the confessed involvement, the issuer does not lose objectivity. The PPD also uses credentials to highlight its position regarding the freedom at stake with the Law on Union Uniqueness. Both PS and PPD also use the mechanism of inoculation to send out a warning regarding the wider issue of Freedom. The core dilemmatic issue in the discourses conveyed is that of Union Freedom against Union Uniqueness.

PCP and Intersindical - They mainly use the mechanism of maximisation of the results from the consultation with workers, whose "smashing majority" had approved the principle of Union Uniqueness, or even the maximisation of the demonstration that occurred on the 14th of January, convened by Intersindical. A stand is taken in favour of "class unionism" as opposed to "union pluralism" (identified as "divisionism") and in favour of "class freedom" versus "abstract freedom" ("formal freedom").

\subsection{From history to the current times: from political and unionist perspectives to the new social and labour dilemmas}

Union organisations were originally formed in the 19th century in capitalist countries, with the establishment of universal suffrage, to extend democracy from the political level to the social level (Lefranc, 1974) through the development of "historical alliances with political parties at a time when universal suffrage was still uncommon" (Costa, 2011, p. 5). This resulted in "distinctive political orientation, relations and divisions regarding unionism up to our time" (Costa, 2011, p. 15).

In a recent review of typological theories on unionism, Costa (2011) refers that "it would not be fair to talk about "pure" unionism models" (p. 35). He contrasts conflict theories with alternative theories to the traditional Marxist theories, set on a pluralist construct and connected with a negotiation unionism, as opposed to contestation unionism.

It was around the notions of conflict and pluralism, unionism and contestation, and negotiation unionism that the two types of federal union association gained form in Portugal - CGTP and UGT, respectively.

The divide at the level of unions remits to the "political and ideological cleavages from 1974-75" (Estanque, 2005, p. 131), embodied in different conceptions of the labour world and different views on unionism (a class-based and 
contestation unionism versus a negotiation and reform-based unionism). These currently face a context of a deep crisis, where an apparently hegemonic neo-liberalism conveys deep financial, economic, social and labour deregulations. This results from the phenomenon of globalisation and hegemony in the neo-liberal forms of governance and control.

On the other hand, at the social level, there are phenomena like "the rising commodification of the social life" (Estanque, 2014), rising inequality or "the impoverishment of wide social layers - in the case of Portugal, boosted by the austerity measures - of professional categories that had aimed for a status close to the lifestyle of the middle-class" (Estanque, 2014, p. 3).

There is the hypothetical emergence of a new social category - "the precarious" - which covers "important sectors of the middle-class" (Estanque, 2014, p. 7) and which is difficult to integrate this category from a unionist point of view. Together with the outsourcing that characterises post-industrial societies, this implies the decline of the working class "that has fed the bases of unionism" (Estanque, 2005, p. 131). Both go hand-in-hand with the emergence of new forms of struggle embodied in inorganic movements that express the dissatisfaction of the new "precarious working class" (Estanque, 2014, p. 17). These are social phenomena that pose questions about the traditional forms of labour organisation and the unionist movement, whether this is based on contestation and class-orientation, or negotiation and action in a neo-corporate logic (Estanque, 2005; Sousa, 2009).

These are questions and dilemmas that are fairly different from the ones posed around the polemic on union uniqueness, namely the dilemmas of the time around union freedom/pluralism versus union uniqueness, class freedom versus formal freedom, specifically regarding the integration of the labour world and its organisation models.

\section{References}

A Lição de 14 de Janeiro deve ser compreendida. (1975, 18 de Janeiro). Avante, p. 2.

Amaral, V. (2013, October). Rhetoric and politics: Some approaches on social psychology and sociology of rhetorical discourse analysis. Paper presented at the International Conference of Rhetoric in Europe, Sarrebrucken, Germany. Retrieved from http://www.unisaarland.de/fileadmin/user_upload/Info/Europa/institute/eir/Proceedings/Paper_Amararal_Virgilio.pdf

Amaral, V. (2015, Maio). Discursos políticos em torno da Lei da Unicidade Sindical e concepp̧ões sobre a organização do mundo laboral: Dos dilemas históricos aos dilemas actuais. Oficina do Ces, $n^{\circ}$ 424, 1-40 (Working Paper).

Amaral, V., \& Pereira, S. (2014). O caso República e a retórica nos discursos políticos: Um estudo descritivo. Análise Psicológica, 1, 105-126. doi: 10.14417/ap.768.

Billig, M. (1991). Ideology and opinions: Studies in rhetorial psychology. London: Sage.

Billig, M. (2012). Undisciplined beginnings: Academic success and discoursive psychology. British Journal of Social Psychology, 51, 413-424.

Brito, J., \& Rodrigues, C. (2013). A UGT na história do movimento sindical português, 1970-90. Lisboa: Tinta-da-China.

Carvalhas, C. (1975, 13 de Janeiro). Deve respeitar-se a vontade dos trabalhadores. Diário de Notícias, p. 7.

Castro, P. (2002). Natureza, ciência e retórica na construção social da ideia deambiente. Lisboa: Fundação Calouste Gulbenkian/Fundação para a Ciência e Tecnologia.

Castro, P., \& Batel, S. (2008). Social representations, change and resistance: On the difficulties of generelizing new norms. Culture \& Psychology, 14, 475-497.

Costa, H. A. (2011). Do enquadramento teórico do sindicalismo às respostas pragmáticas. In E. Estanque, \& H. A. Costa (Eds.), 0 sindicalismo português e a nova questão social: Crise ou renovação? (pp. 13-48). Coimbra: Edições Almedina.

Estanque, E. (2005). Trabalho, desigualdades sociais e sindicalismo. Revista Crítica de Ciências Sociais, 71, 113-140.

Estanque, E. (2014). Rebeliões da classe média? Precariedade e movimentos sociais em Portugal e no Brasil (2011-2013). Revista Crítica de Ciências Sociais, 103, 53-80. doi: 10.4000/rccs.5540.

Grande manifestação da Intersindical: "Quem tem medo do povo?". (1975, 17 de Janeiro). Alavanca, p. 2, 4.

Lefranc, G. (1974). O Sindicalismo no mundo. Lisboa: Europa-América.

O PPD contra os Sindicatos únicos. (1974, 8 de Outubro). Povo Livre, p. 1.

Os sindicatos únicos são o caminho mais certo para o regresso da opressão. (1975, 16 de Janeiro). Povo Livre, p. 3.

PCP (1975). Sobre a manifestação pela unicidade sindical - Nota da Comissão Política do Comité Central do PCP [Online]. Retrieved from: http://www.pcp.pt/joomla/index.php?option=com_content\&task=view\&id=268\&ltemid=154 (Jannuary 12, 2015).

Política clara e transparente. (1975, 23 de Janeiro). Avante, p. 2.

Perelman, Ch. (1997). O Império retórico: Retórica e argumentação. Lisboa: ASA.

Perelman, Ch., \& Olbrechts-Tyteca, L. (2006). Tratado de argumentação. Lisboa: Instituto Piaget.

Potter, J. (1996). Representing reality: Discourse, rhetoric and social construction. London: Sage.

Silva, M., Nunes, A., Cabrita, D., Martins, E., Rocha, F., Cartaxo, J., \& Barreto, K. (2011). Contributos para a história do movimento operário e sindical. Das raízes até 1977 (Vol. 1). Lisboa: CGTP-IN / Instituto Bento de Jesus Caraça.

Sousa, H. (2009). Há Futuro para a concertação social? Os sindicatos e a experiência neo-corporativa em Portugal. Dissertação de Mestrado em Ciências políticas, Faculdade de Ciências Sociais e Humanas da Universidade Nova de Lisboa. 
Unidade: A vontade dos trabalhadores. (1974, 9 de Dezembro). Alavanca, pp. 1-2.

Valente, J. (2001). O Movimento Operário e Sindical (1970-1976): Entre o corporativismo e a Unicidade. In J. Brito (Ed.), O País e a Revolução (pp. 209-251). Lisboa: Círculo de Leitores.

Van Dijk, T. (2006). Ideology and discourse analysis. Journal of Political Ideologies, 11(2), 115-140. doi: 10.1080/13569310600687908. Varela, R. (2014). História do povo na revolução portuguesa 1974-1975. Lisboa: Bertrand.

Zenha, F. S. (1975, 7 de Janeiro). Unidade sindical ou medo à liberdade? Diário de Notícias, p. 7.

Zenha, F. S. (1975, 17 de Janeiro). O Partido Socialista não se deixará satelizar. Portugal Socialista, pp. 6-7. 